УДК 930.2:003.072 + 930.2:003.074

Lyubov' Stolyarova, Svetlana Koroleva

\title{
SERGEY KASHTANOV. HISTORIOGRAPHER OF THE RUSSIAN AND EUROPEAN MIDDLE AGES
}

The article is devoted to the scholarly work of an outstanding Russian historian, a corresponding member of the Russian Academy of Sciences Sergey Mihailovich Kashtanov. Without exaggeration, he can be considered an actual classic of Soviet and Russian academic historical thought. The list of his professional interests alone is impressive as it is ranges from source study and archaeography to historiography and the history of state institutions; from diplomatics to historical demographics and geography. Sergey Kashtanov is a mediaevalist, whose research is focused on mediaeval Russia which he studies referring to the historical context of European countries between the Middle Ages and the Early Modern Period. As a result, Kashtanov's contribution to comparative mediaeval history is significant. Additionally, Kashtanov's works on diplomatics are recognized worldwide as in them the scholar puts forward original methods of mediaeval acts analysis. Professionally, Sergey Kashtanov may be characterized both as a theoretician and practitioner, a researcher of feudal property; a scholar that proposed a number of new methods of analysis in paleography, filigree studies, and codicology; and, finally, as an observant and witty historiographer. Being a follower of A. A. Zimin and S. O. Schmidt, S. M. Kashtanov is a rare representative of Russia's high academic tradition of humanities thought dating back to the prerevolutionary era. This unique atmosphere which is, sadly, becoming nonexistent, is permanently present in the life and work of the main character of the article.

Keywords: S. M. Kashtanov; comparative mediaeval studies; historiography; source studies; diplomatics; history of feudalism.

Статья посвящена научному творчеству выдающегося русского историка, члена-корреспондента РАН Сергея Михайловича Каштанова. Он без преувеличения может быть назван действующим классиком советской и российской научной исторической школы. Один перечень его профессиональных интересов впечатляет: от источниковедения и археографии до историографии и истории государственных учреждений; от дипломатики до исторической демографии и географии. Сергей Михайлович - медиевист, его изыскания посвящены средневековой Руси, которую он исследует, обращаясь к историческому контексту европейских 
стран Средневековья - раннего Нового времени. В связи с этим велики заслуги Каштанова в области компаративной медиевистики. Заслуженным признанием мирового исторического сообщества пользуются труды Каштанова-дипломатиста, автора оригинальной методики дипломатического анализа средневековых актов. В профессиональной деятельности Сергея Михайловича удивительным образом сочетаются теоретик и практик; исследователь феодального землевладения, иммунитетов, финансовой политики средневековой Руси и создатель концепции феодальной собственности; ученый, предложивший ряд новых методик в области палеографии, филиграноведения, кодикологии, и остроумный наблюдательный историограф.

Ученик А. А. Зимина и С. О. Шмидта, С. М. Каштанов является одним из немногих носителей высокой академической традиции русской гуманитаристики, восходящей к дореволюционной эпохе. Эта уникальная и, к сожалению, уходящая среда явственно проступает через жизнь и творчество главного героя статьи.

Ключевые слова: С. М. Каштанов, компаративная медиевистика, историография, источниковедение, дипломатика, история феодализма.

Sergey Mihailovich Kashtanov was born on January 29, 1932 in Leningrad, the son of M. F. Kashtanov, a military engineer, and I. S. Kashtanova, the daughter of a prominent court maker of medals, S. A. Grilihis. In 1954 S. M. Kashtanov graduated with honors from the Mos-

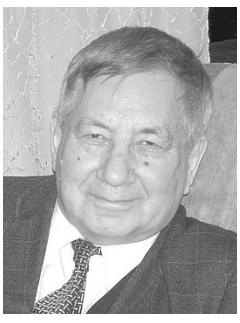
cow State Historical Archives Institute (MSHAI). A brilliant graduate of the Department of Auxiliary Historical Disciplines of MSHAI, between 1992-2011, Kashtanov was at the Department of Historical Sources Study and Auxiliary Historical Disciplines ${ }^{2}$.

At present he is at the Higher School of Sources Study, Auxiliary and Special Historical Disciplines of the Russian State University of the Humanities. He was a student of A. A. Zimin, a permanent member and even a historian of the famous study group of S. O. Shmidt, which is dedicated to the study of sources. He has created a special branch in history studies and has become the founder of his own scientific school, formed around him in the Historical Archives Institute. In 2011, S. M. Kashtanov was awarded the title of Distinguished Professor of the Russian State University of the Humanities.

After graduating from MSHAI in 1954 and completing his postgraduate studies in 1954-1958, S. M. Kashtanov began to work in 1956 as a research fellow of the Institute of History of the Academy of Sciences of the Soviet Union, which in 1968 was divided into the Institute of History of the USSR and the Institute of World History of the Academy of Sciences.

In the first one (which was renamed in 1991, the Institute of Russian History) S. M. Kashtanov worked until April 2001, when he joined the Institute of World History of the Russian Academy of Sciences at the invi-

${ }^{2}$ Detailed bibliographic essay about S. M. Kashtanov vide: [Столярова]. 
tation of the director, Academician A. O. Chubaryan. In the Institute of History of the Academy of Sciences of the USSR, S. M. Kashtanov worked first in the division of sources study and publication, under the leadership of A. A. Novoselsky, and since 1963 he worked in the division of the History of the USSR of the feudal period, which was led by L.V. Cherepnin.

After the latter's death in 1977 the division was led first by A. A. Preobrazhensky and then by N. A. Gorskaya. In the 1990s it was called the division of Russian History of the Middle Ages and Early Modern Period. At the initiative of N. A. Gorskaya in 1995, S. M. Kashtanov was elected as head of the sector, and in 1997 S. M. Kashtanov was elected a corresponding member of the Russian Academy of Sciences.

Since 1987, at the invitation of A. L. Stanislavsky, Kashtanov began to work part-time at the Department of Auxiliary Historical Disciplines of MSHAI where he conducted workshops for auxiliary historical disciplines and seminars on the study of sources. For twenty-five years he led a research seminar, which he set up personally, "Chronology of the History of Russia in the $10^{\text {th }}-18^{\text {th }}$ Centuries". Under his leadership dozens of graduate theses were written, as well as more than twenty masters and three doctoral dissertations. His courses, such as "Notes of foreigners about Russia" and "Russian diplomatics", were brilliant in form and interesting in content, and were popular in the Russian State University of the Humanities, attracting not only students but also postgraduate students. In June 2011, S. M. Kashtanov created the Department of the Higher School of source, auxiliary and special historical disciplines and became the head. Sergey Kashtanov is an eminent historian, expert on source studies, a diplomatist and archaeographer, and the most renowned specialist on the socio-economic and political history of Russia from the $10^{\text {th }}$ to $16^{\text {th }}$ centuries, source studies, diplomacy, diplomatic codicology, archaeography and the study of watermarks.

S. M. Kashtanov is a distinguished scholar, author of approximately 700 scientific research papers, including eight monographs. He combines in his works concrete historical research with the development of political, economic and philosophical issues, as well as the theory and methodology of archeology, the study of sources and auxiliary historical disciplines. Areas of research in the activities of S. M. Kashtanov are so diverse and the results are so great that we believe it is necessary to analyze them in this essay systematically and in detail, highlighting certain areas of his research.

\section{Works in the Theory and Practice of Medieval Texts Archaeography}

The most important direction in the development of the creative work of S. M. Kashtanov became the theory of archaeography and publication sources (practical science of archaeography of medieval texts). It is symbolic that with his activity as a medievalist S. M. Kashtanov's career began 
with the publication of returns' books of the Trinity-Sergius Monastery [Отдаточные книги]. Kashtanov's preparation for printing these books began at the initiative of A. A. Zimin (1920-1980), who in the mid-1950s involved his pupil in the publication of "Records of Russian law". In this edition Kashtanov prepared for publication a number of charters, ukazy charters and private acts from the $14^{\text {th }}-17^{\text {th }}$ centuries. He compiled a detailed, historical and legal review of immunity acts from the $14^{\text {th }}-16^{\text {th }}$ centuries, as well as acts of feudal land ownership and management in the first half of the $17^{\text {th }}$ century [Памятники русского права]. In 1961 Kashtanov published two charters of Pskov monasteries from 1510 [Каштанов, Робинсон].

Later, under the direction of A. Nasonov he prepared for publication two previously unpublished, abbreviated chronicles of 1493 and 1495 [Сокращенный летописный свод 1493 г.; Сокращенный летописный свод 1495 г.]. This work laid the foundation for the publication of a number of the most important sources on the socio-economic and political history of Russia from the $14^{\text {th }}-17^{\text {th }}$ centuries. In 1963, Kashtanov published a drawing of land of the $16^{\text {th }}$ century - the earliest known Russian drawing of that type [Каштанов, 1963в]. In 1968, he turned to the study of lists of $u k a z y$ ratifications in 1630 in the Uzhgitsk parish, which included the preserved text of the Charter from 1559/60 and included testimonies of how the Russian Zemstvo reform unfolded. Text of this newly discovered source was prepared for publication, accompanied by a detailed historical and diplomatic study [Каштанов, 1968].

S. M. Kashtanov is the author of the first handbook on the historiography of the medieval Russian Diplomatic Act, which is "Hronologicheskij perechen' immunitetny'h gramot XVI v." ("Chronological list of immunity ratifications charters of the $16^{\text {th }}$ century") [Каштанов, 19586; Каштанов, 1962; Каштанов, Назаров, Флоря]. It provides information about the scripts, lists, publications and references to charters and charters of $u k a z y$ from 1504-1584. Kashtanov specified headers, charters and acts with information about deacons, boyars and treasurers, who participated in the issuance of letters, as well as data on the later confirmations. He sought to maximize the number of surviving originals and lists of immunity letters, as well as publications and literary references on each of them [Каштанов, 19586; Каштанов, 1962; Каштанов, Назаров, Флоря].

After the release of the first two parts of the chronological list Kashtanov managed to identify a significant number of additional immunity acts. Many acts and much bibliographical information were listed by V. A. Kuchkin, V. D. Nazarov and B. N. Florya. Therefore, the third (optional) part of the chronological list in 1968 was published in collaboration with Nazarov and Florya. Kuchkin, to whom Kashtanov expressed his heartfelt gratitude in this publication, refused the recognition of his co-authorship in the publication. At the moment there is an urgent need to reprint Kashtanov's chronological list, with the additions and clarifications to be made, taking into account not only the newly found acts, but also the achievements of archaeography and diplomacy in the last four decades. 
The publication of previously unknown acts of Trinity-Sergius, Cyril Belozersky, St. Paul Obnorsk, Serpuhov Vladychny, Ivanopredtechensky, Yakovlevsky and Zheleznoborkovsky monasteries, as well as letters from the archives of the Kazan diocese has become an important part of the fundamental monograph of Kashtanov, "Ocherki russkoj diplomatiki" ("Essays of Russian Diplomatique”) (1970) [Каштанов, 1970a, c. 341-448]. This work began in a series of scientific publications of documents of the monasteries and cathedrals of the Russian state.

In the mid-1950s, preparations began on the publication of the archive of the Trinity-Sergius Monastery of the $16^{\text {th }}$ century under the generic name of "Acts of the Russian State" (hereinafter referred to ARS). The basis for the publication stemmed from copies of the Trinity acts, made by S. B. Veselovsky. At the same time, an acts group was created and headed by I. A. Bulygin. S. M. Kashtanov was connected with the work on the first volume of the ARS in 1974, primarily dealing with the final stages of preparation for publication. Kashtanov radically re-edited titles, made a number of comments and captions, and wrote a general introduction to the volume. In 1975, the first volume of the ARS was released [Акты Русского государства]. Preparation for the publication of this and subsequent volumes was accompanied by heated discussions about the rules of transferring texts of the Troiczk Acts. At the request of members of the forensic team of the Academy of Science of the USSR from 1975-1977, Kashtanov made a "Supplement" to the rules of publication of ARS, prepared by Bulygin [Правила издания]. In 1987, based on the "Supplements" Kashtanov wrote a detailed "Guidelines" for the publication of ARS, based on principles that were gradually developed by him of complicated diplomatic reproduction However, neither the Supplements nor Guidelines were published at the time for personal reasons ${ }^{3}$. Extensive "Guidelines" were published only in 1998, although they were already actively used in the manuscript publications by the publishers (and not only for ARS).

S. M. Kashtanov was engaged for most of his life with the filing and publication of the archive of the Trinity-Sergius Monastery. He discovered and first published previously unknown scripts and lists of the Troiczk Acts from the $15^{\text {th }}-16^{\text {th }}$ centuries. In 1966 he published the text of the reconstructed general chapter of the Trinity-Sergius Monastery in all fiefdoms of 1550 [Каштанов, 1966]. Despite the fact that S. M. Kashtanov, already in the middle of the 1970s, recognized the need for principles in reproducing diplomatic texts and medieval charters, he did not formulate the rules until the end of the 1990s because he was unable to implement them in practice.

Between 1950-1980 the manner of publishing the text (simplified critical, complicated diplomatic or complicated linguistic) and the volume and nature of the treatment of an archaeographically published source in

\footnotetext{
${ }^{3}$ On the history of the preparation of the first volume of "Akty' Russkogo gosudarstva" ("Acts of the Russian state") and discussions around the rules on transferring their text vide: [Каштанов 1998, с. 234-236, 284-285].
} 
the USSR often depended not only on the will of the publisher, but also on the traditions of reproducing texts within a particular serial edition (for example PSRL) or the capabilities for printing in publishing facilities.

Furthermore, it was between 1960-1990 that the position of "reductionists" found reinforcement in the thesis: "for a historian content of the source is enough, details are for philologists!" 4 As a result most often "complicators" were linguists, who gradually developed the principle of reproduction of the text "to the letter, line for line" [Успенский сборник].

The linguistic principle of publishing the text at a time when it was just forming, was carried out in ways very close to the medieval copie figurée (painted copies), prompting the appearance of the manuscript (handwriting, small and accent marks, special text layout, etc.) [Каштанов, 1988a, с. 33]. We believe that this was due to extraordinary technical and financial difficulties that accompanied the preparation of photographic and facsimile reproductions of texts, making the facsimile (reproduction) type of publication hardly an affordable luxury. Copie figurée, probably seemed to be a way out of the situation. In the age of computer technology, complexities like these do not seem to be a problem. Numbers of "complicators" were supplemented by historians. However, the debate about the appropriateness of a complicated transfer of texts only intensified, and was now being waged not only between historians and linguists (supporters and opponents of "reductionists"), but also between the supporters and opponents of the complicated rules of reproducing texts: diplomatic and linguistic.

In these disputes, Kashtanov always remained true to the principles that he developed for a sophisticated manner of publishing a diplomatic text, part of the processing of which is archaeographic preparation with widely developed aids for investigation. Font-imitators, which are a constant attribute of modern copie figurée, as well as publication of medieval texts with minimal or no archaeographic preparation, cause him constant bewilderment and even irritation.

Since the early 1980s S. M. Kashtanov is increasingly drawn to the problems of the theory and practice of archaeography. In 1983, he formulated the basic principles of the reproduction of the text of the acts' material, based on his experience of research of ancient Russian public law acts of ratification [Каштанов, 1983]. In the 1970s he, together with A. A. Zimin, took part in the forthcoming edition (prepared by L. I. Ivina) of the Acts of Moscow Simonov Monastery, in which he accomplished full archaeographic processing of all of the identified Simonov acts of the $16^{\text {th }}$ century [Акты феодального землевладения].

In 1985 S. M. Kashtanov co-authored with A. L. Horoshkevich the guidelines for the publication of the Lithuania metric. This edition was the first attempt to apply to the documents the Lithuania metric rules,

\footnotetext{
${ }^{4}$ Later as the ideological historians - "uproshhencev" ("simplificators") - spoke the member of act group of Institute of the Russian history N. I. Nikitin [Никитин].
} 
which were developed for the publication of the Acts of the Russian state of the $16^{\text {th }}$ century [Каштанов, Хорошкевич]. From 1985-1988 a series of articles by S. M. Kashtanov appeared, which demonstrate the analysis adopted in contemporary Western European medieval studies for the principles of the Latin edition of ratification acts [Каштанов, 1985; Каштанов, 1986а; Каштанов, 19866; Каштанов, 1987; Каштанов, 19886]. In the mid-1980s, S. M. Kashtanov was engaged in studying and preparing for publication two "Greek" ambassadorial books of the $16^{\text {th }}$ century. In 1993 his fundamental research on the royal Synodikon of the 1550's appeared, which included the Greek embassy book № 1. Publication of this text was made in accordance with complicated rules, subject to all the lexical and orthographic features of the original, with detailed paleographic notes, historical and geographical comments. The full text of the ancient "Greek" ambassador's book was published as a joint project between S. M. Kashtanov and L. V. Stolyarova while B. L. Fonkich became involved only in 2004 [Россия и греческий мир].

In 1996, Kashtanov published previously unreleased letters of Pereslavl and St. Paul Obnorsk and Suzdal Intercession monasteries, including two bills of sale found by him from the $15^{\text {th }}$ century and three charters from the beginning of the $16^{\text {th }}$ century, and issued a series of acts of the cathedral archives of Balahna and Nizhny Novgorod and certificates relating to the history of Belomestny's tenure in Russian cities during the "boyar rule" [Каштанов, 1996a]. In 1997, S. M. Kashtanov together with O. I. Horuzhenko prepared 11 letters for publication from the $16^{\text {th }}$ century to the beginning of the $18^{\text {th }}$ century, from the archives of the Archangel Cathedral of Moscow [Грамоты из архива, с. 390]. One of the published acts - ukazny act of 1546 - remains in the original, and the remaining 10 are extant copies from the beginning of the 1730s. They have been found in the Russian State Archive of Ancient Acts (RGADA) as part of the Senate book, number 781. Publication is accompanied by a detailed investigation of the Archangel acts [Ibid, c. 390-406], in which it is demonstrated that the first land grants to the Archangel Cathedral were not made by the grand dukes of Moscow, but by grand and feudal lords, members of the house of Borowski-Serpukhov. The authors presented data showing an increase in tenure of the cathedral since the middle of the $15^{\text {th }}$ century, analyzed each of the letters published, and reproduced information about scribal descriptions that were not reflected in the existing lists. They described in detail the paleographic and codicological features of the collection, which included copies of the letters preserved, focusing on the paper watermarks. The authors found that in the stationery copies of letters Dutch paper was used, and in the drafts, a rougher Russian paper. Study of the Senate book number 781 allowed the authors to come close to the problem of copying texts by the "homegrown archaeographers of the first third of the $18^{\text {th }}$ century” [Ibid, c. 406].

An important development in the theory and practice of publishing medieval texts became S. M. Kashtanov's monograph, "Archaeography of 
acts", which is devoted to the specifics of publishing documentary sources in Russia and abroad [Каштанов, 1998]. Acts archeology is considered by Kashtanov as a special branch of science, which allows him to clarify what constitutes an "act", determine its place in the general classification of the historical sources and compare methods of an act's archaeography in different countries. The book analyzes the modern principles of the Latin edition of letters, and also features the latest Russian publication on acts, which touches upon the controversial issue of transferring the text of medieval charters, especially the preparation of legends, descriptions of filigrees, stamps, handwriting, etc. A special section of the book consists of the guidelines for the publication of ARG, which summarizes a wealth of experience of domestic and foreign archeography. In the book's conclusion, which is eloquently titled, "Whither goes acts' Archaeography?", Kashtanov reflects on the general trends of modern domestic archaeography, in which it has become almost fashionable to advocate simple principles for publishing sources. The scientist is convinced that "the publication of sources is not a mass production, but an art that requires highly skilled labor, morality and the pursuit of virtuosity" [Ibid, c. 298].

Occupying a special place among S. M. Kashtanov's works is his publication of obelno-criminal record certificates of Ivan III and Vasily III, issued in 1504 to the Spassky Valaam Monastery (2000). These certificates are preserved in Swedish translation, compiled between 1618-1619 [Новонайденная жалованная грамота] ${ }^{5}$. The published letters preceded a detailed archaeographic introduction. Kashtanov showed that the letter of 1504 was part of a series of immunity letters of the period of joint management of Ivan III and Vasily III in Novgorod and is the earliest known act issued to the Valaam Monastery. Kashtanov put next to each other the letters of 1504 and the charter of Novgorod Volotovo Monastery in 1500, suggesting the existence of some general wording of the joint letters of Ivan III and Vasily III. However, he showed that Form of the 1504 certificates was not used in the later preparation of the acts, which were issued to the Valaam Monastery (1507, 1540 and 1578 years.).

Not limiting himself to the publication of the Swedish translation of letters from the original Stockholm archive, Kashtanov prepared the letters for translation from Swedish to Russian. Compiled by him, notes on the translation contain detailed, textual and diplomatic comments. The most important part of the publication of the letters of 1504 is the reconstruction of the text of its unpreserved (lost) Russian copy, from which a Swedish translation was made in the $17^{\text {th }}$ century. Notes on the reconstruction contain conjectures for justification, based on the forms of charters of Ivan III and Vasily III from 1499-1500. As a supplement to the publication of letters

${ }^{5}$ The archaeographic introduction, publication of the Swedish text, its translation and reconstruction of the lost original, as well as the notes to the text, translation and commentary are prepared by S. M. Kashtanov [Новонайденная жалованная грамота, с. 419-429, 434-443]. E. E. Matveeva compiled the detailed index-slovnik to the Swedish text [Ibid, c. $422,430-433]$. 
in 1504 Kashtanov placed a fragment from the scribe book of Vodskaya from the 90's of the $16^{\text {th }}$ century. It contains a description of the attached properties of Valaam Monastery, as well as Serdovalsky and Ilomansky churchyards in Korelsky County. Prior to the publication of the "Swedish" act, domestic archaeography had not dealt with the scientific publication of a source, especially one that was preserved in later copies in a foreign language, accompanied by its translation and detailed reconstruction of the lost original text.

In 2006, S. M. Kashtanov published a text of the Russian-Livonian contract in 1535, which is an important source for the history of international relations and foreign policy of Russia and Livonia in the $16^{\text {th }}$ century [Каштанов, 2006a]. This treaty was the first Russian-Livonian written agreement made under Ivan IV; particularly, it was drafted during his childhood under the regency of Elena Glinskaya. The Treaty of 1535 was a continuation of a series of Russian-Livonian peace treaties signed by the grandfather and father of Ivan the Terrible in 1503, 1509, 1514, 1521 and 1531. The Treaty of 1535, agreed upon in Novgorod, provided a peaceful development of relations between Russia and Livonia for the following 17 years, until October 1551. In August 1550 the government of Ivan the Terrible entered into a new agreement with Livonia. Additionally, the agreement in 1554 was the last peace treaty signed between Russia and the Livonian Order on the eve of the Livonian War. Despite the fact that the agreement of 1535 has been repeatedly mentioned in academic literature, it has not been published. S. M. Kashtanov not only was the first to publish the original text, following the principles of complicated practices of publishing diplomatic texts, but also he devoted a separate extensive study to the 1535 agreement. S. M. Kashtanov was able to specify the date of the agreement, which previously was attributed to 1534, and to adjudge the circumstances that led to its signing [Ibid, c. 167-180].

The agreement of 1535 is written on two sheets of parchment, which were bonded by drooping seals [РГАДА, ф. 64, оп. 2, № 7, л. 1-2]. Only three of the original seals survived: two of them belonged to the governors of Novgorod Princes, Boris Ivanovich Gorbaty and Mihail Semenovich Voronczov, and another to the Pskov governor, Dmitry Semenovich Voronczov. The parts of the surviving seals include: the Pskov governor's, Prince Mihail Ivanovich Kubensky's, seal with only the "chicken foot", on the cord on parchment; Master Hermann von Bruggenei's seal of Livonian Order with just a parchment strap connecting the print with a letter; the Archbishop Thomas of Riga's seal with a hole for parchment ribbon; and Bishop John (?) of Dorpat's seal with part of the silk cord threaded through the parchment. On one sheet of parchment was placed the Russian text of the treaty, written in cursive, and on the other, the German text of the treaty, made in gothic italics. S. M. Kashtanov suggested that the treaty of 1535 was drawn up in four copies, two in Russian and two in German. Connected in pairs, Russian and German instances formed two "trays". First, they were sealed by the Russians, and then in Livonia, one of the trays 
would be returned to Novgorod, and the other remained in Livonia [Каштанов, 2006а, c. 180].

Both texts of the treaty of 1535 were published by Kashtanov, and were accompanied with a detailed paleographic study that meticulously describes the present-day size, presents a reconstruction of authentic dimensions of both sheets [Ibid, c. 182-190] and characterizes material for writing [Ibid, c. 190]. Described in detail are the outward signs of both texts and their handwriting attribution, as well as the density of letters of German and Russian texts [Ibid, c. 190-195].

Special attention is given to the seals and how they attach. For the first time in national historiography, the course of the cord when creating a mounting press was analyzed in detail, which is important for the reconstruction procedure, especially when connecting the cord with parchment and seal. The latter is essential in the study of official practices in the 16th century. When investigating how the image is placed on the seals and how the inscriptions are imprinted on them, there are several options in the attribution of images. Very important is Kashtanov's placement of photographs and numerous tables with detailed measurements of three surviving seals in the archaeographic part of the publication. Impressive is the research on the parchment ribbon, on the unpreserved print number 5 , number 7 , and on the cord printing and methods of attachment of seals $1-7$, which provide important information for diplomatists who want to learn about the process of drawing up and certification of original acts at different times and in different offices within different states [Ibid, c. 195-224].

S. M. Kashtanov investigated and characterized labels and notes, available on the pages of the manuscript, which reflect the process of working with the contract through the $16^{\text {th }}-18^{\text {th }}$ centuries. There are traces of life of the text and its subsequent fate in the archives [Ibid, c. 224-226]. Special sections are devoted to the analysis of the introduction of archaeographic damage to manuscripts [Ibid, c. 226-227] in characteristic folds of the parchment and in folded manuscripts [Ibid, c. 227-230]. Kashtanov found that the method for folding the manuscript was established long ago. A diploma was wrapped in coarse paper in the $18^{\text {th }}$ century, which produces the likeness of an envelope. On the cover, marks from the $18^{\text {th }}$ and $20^{\text {th }}$ centuries reflect certain stages of research and archival work on the script [Ibid, c. 230].

S. M. Kashtanov explores lists of the treaty of 1535 , which (in its Russian and German versions) appear in a collection of copies of Russian-Livonian contracts from 1509-1554 kept in the fund of "portfolios" by GF Miller. Identification of the watermark on the manuscript allowed S. M. Kashtanov to conclude that the paper of a book in a German copy of the agreement of 1535 was made in the 60's in $18^{\text {th }}$ century. That was also the time when the paper for the Russian copy was made, the last leaf of which has a watermark, referring to the period from 1754-1765. Kashtanov found that the copies were created simultaneously by different scribes and then intertwined 
together. He suggested that all the work was carried out under the direction of GF Miller, who in March 1766 headed the Moscow archives of the State College of Foreign Affairs. Copies emerged during GF Miller's initial work in Moscow on the archives board, specifically from 1766-1767 [Каштанов, 2006a, c. 230-235].

A special section of the archaeographic introduction is devoted to references to the 1535 Russian-Livonian agreement in archival inventories. S. M. Kashtanov found that, based on inventories of the Ambassadors (Foreign Office) archive, in 1612 all the seven seals of ratification in 1535 were still in order. By 1626, only five seals survived, and two of them were separated from the document, although they were "screwed" to it. In 1673 "screwed" seals fell out and were already lost [Ibid, c. 235-237].

S. M. Kashtanov published both texts of the 1535 treaty (Russian and German), fully preserving the original spelling [Ibid, c. 237-273]. In the introduction Kashtanov provides a detailed explanation of the archaeographic principles of publishing the 1535 Treaty [Ibid, c. 181-182]. When publishing the Russian text of the treaty, outdated letters of the Cyrillic alphabet were not replaced by new ones. Superscript letters were in italics. Letters, appearing in the text when opening the cuts, were placed in parentheses. In the German text, spelling was also not modernized. The letter «V» is not replaced by «u»; «i $»$ was not replaced by «j» and vice versa. The combination of letters «sh» was not replaced by «sch». Common in the German texts were abbreviations without word endings, and the missing letters were placed in parentheses. Colons, often occurring after abbreviated words such as «f:» and «ved:», were not reproduced. Lost or damaged and difficult to read the letters in Russian and German have been placed in square brackets. Punctuation, being an important part of the interpretation of the text, was used in accordance with modern standards. In some cases remarks were made in notes about German punctuation. Kashtanov marked the ends of the lines in both texts with a vertical line. A line number was placed in parentheses at the beginning of each line (in the manuscript that was not the case). The text of the Russian and German originals was split by the publisher into chapters, numbered with Roman numerals, which were placed in brackets. The use of numbered chapters as well as numbered lines permits the correlation of similar content in the Russian and German texts. In the original German text, discrepancies are provided, as in copies of the $18^{\text {th }}$ century text done by GF Miller [Ibid, c. 273].

Publication of the Treaty of 1535 is not limited to the transfer of its diplomatic text, but also accompanied by photo reproduction, which decreased the original size by half (as an appendix to the publication). Unfortunately, printing a photo of the treaty in its original size proved technically impossible for reasons that were beyond the publisher's control. However, having a diplomatic version and a facsimile proves extremely important both for specialists who study diplomatic acts and for paleographers. 
The Russian and German texts both mention the Treaty of 1535 and are accompanied by detailed paleographic notes. Kashtanov detailed the smallest damage to the text, such as scuffed, stained marks and dampness, which he anticipated might affect the safety and quality of future readings; he also noted the significant damage and lost parts of the text, which would produce unclear readings. The researcher also noted the presence of large and small initials, indicating their size. Reoccurring throughout the text are distinctive and unusually written letters (for example, decorated with dots or strokes) and ligatures-an important feature of individual handwriting [Каштанов, 2006a, с. 243-254, 261-273]. All these details are carefully marked, which testify how the archaeographer treats the text as a significant historical artifact, even describing the text's physical condition at the time of publication. Such precision is just as important for the archivist or researcher of documentation practices and of subsequent record keeping, as it is important as an archival document for historians or philologists. After all, in the future you never know to what purpose researchers will need the script and to what extent they will require detailed information on the text!

Particular attention should be focused on aids used to find the text (title, legend, direction lists for Russian and German texts, as well as a list of correlated terms of Russian and German). The index includes all the words of the original Russian and German texts of the agreement, and different forms of writing the same words appear as separate words. A List of relations in terminology within Russian and German copies of the treaty on 1535, includes the most essential, primarily legal, concepts. The list is not restricted to nouns and adjectives. It also includes verbs, adverbs, prepositions, etc. The list is based on Russian terms, which have German equivalents [Ibid, c. 278-297]. In 2014, with minor editorial changes and editions, the text of the Treaty between Russia and Livonia on 1535 was re-published in the additions to the monograph on the history of princely offices of medieval Russia [Каштанов, 2014].

In 1998, publishing a book on archaeography of acts and modern principles of publishing of Latin and ancient parchments, S. M. Kashtanov formulated his credo of an archaeographer, insisting that it is "art" and "the pursuit of virtuosity" [Каштанов, 1998, с. 298]. Publication of the Russian-Livonian Treaty of 1535 is fully consistent with this definition. It amazes and delights. It urges us to treat publishing material very honestly, carefully and accurately, for there is a deep moral attitude of the historian to document not only the historical source, but also the historical artifact. Such a sentiment discourages "simplistic" archaeography, which is nothing more than laziness and an unwillingness to deal with the tedious and labor-intensive operations to do the necessary archaeographic work on a document.

In 2006 S. M. Kashtanov, drawing upon complex rules, published the petition of the Duke I. B. Molozhsky to the Grand Duke Vasily III about Fugitive menials. The text of this unique source for the history of serfdom is 
preceded by a detailed diplomatic and paleographic study of the document, which helped to clarify its date. Kashtanov believes that the petition was drawn up shortly after the death of Dmitri Ivanovich Zhilka, of Uglich, i. e. between 1521-1522 [Каштанов, 20066].

In 2012, S. M. Kashtanov published a monographic study of the 1482 act of the Moldavian ruler Stephen III the Great and for the first time, using his own complex rules [Каштанов, 2012]. The Moldovan act was discovered in the archives of Vatopedi Monastery on Mount Athos in the early 1970s, by one of the pupils of Professor Andre Guillou. In 1974, Guillou gave two photocopies of the certificates to Kashtanov, offering to publish it.

In 1999, during an expedition to Mount Athos, S. M. Kashtanov tried to find this letter in the repository of Vatopedi Monastery but failed. The documented listing of the act, which was provided by Guillou, had changed and was lost. All attempts by Vatopedi monks to establish a new listing of the Moldovan act and to determine its topography proved futile. This document was not known to the publishers of a fundamental series of Moldovan acts of the $14^{\text {th }}-17^{\text {th }}$ centuries from the 1960-1970s, and photocopies of Guillou were the only documentary evidence of its existence. Kashtanov decided to publish the Moldovan document by its photocopies. Poor preservation of the document and the poor quality of its photographic reproduction demanded considerable effort by Kashtanov in order to complete the reconstruction of the text.

The book is an attempt to solve the questions of who were counterparties of the land deal, which was legitimized by Stephen III, and was there any kinship links between the recipients of Gergeshti village, some men called Costa and Jonas, with a donor of this village, Marga. After delving into genealogy, researchers determined that both the donor and the recipient of the village Gergeshti, which by the way was mentioned in this document for the first time in written history, belonged to the family of Mr. Negri, a prominent landowner of the Moldavian principality and associate of the magistrate, Alexander I, The Good.

Thus, S. M. Kashtanov introduced into scientific circulation complicated documentary sources, primarily of the 16th century. His work in the field of archaeography contributed to the emergence of new views of the main trends in the theory and practice of modern editions of medieval texts, significantly advancing the work of archaeographers in Russia and abroad. The rules of archaeographic text processing, which S. M. Kashtanov follows today, evolved gradually. If in the early stages of his work the researcher remained faithful to the principles of complexity in the reproduction of the text depending on the time of writing (i. e., the older the source, the harder the rules of reproduction of its text; in texts at the beginning of a new time and the older ones, content is more important than the form; meticulous fixation upon lexical spelling and paleographic features of documents are not required), then during the mid-1980s to early 1990s, the researcher developed his own sophisticated rules for publication with each rule serving an important role in the publication process. In the first stage of his career, 
Kashtanov was influenced by A. A. Zimin, who offered a differentiated approach to the choice of the degree of difficulty of archaeography, depending on the antiquity of the published source. At a time when the science of historical studies is increasingly being developed through differentiation and as various specializations and disciplines are synthesized, whereby the circumstances of a source's origin are defined more and more with the help of the latest techniques, codicology, paleography and diplomatics, Kashtanov is increasingly aware of the importance of research in original documents. Careful determination of all signs of external and internal forms of the document appears as the only way to study the circumstances contributing to the creation of the source and the destiny of its archival history.

The whole value of the works of Kashtanov as archaeographer unfortunately is not yet fully recognized and not always accepted by the scientific community, and his rules for the transfer of text are even considered unenforceable [Кистерев, с. 311-334]. But no matter how one looks at Kashtanov the archaeographer-that is, is his archaeography a form of art for art's sake, or is it a necessary component of a technique to publish the texts of the Middle Ages and early modern times-one thing is certain: he advanced the development of document studies as a science, and without him it would be difficult to imagine the present state of domestic and foreign medieval historiography.

The significant impact of Kashtanov as archaeographer is represented in works of his school and his followers (K. V. Baranov, T. V. Gimon, K. Yu. Erusalimsky, L. A. Kirichenko, N. A. Komochev, L. V. Stolyarova, O. I. Horuzhenko, et al.). Their research and publishing activity (with the wealth of variety developed by the new generation of archaeographers, offering rules for transmitting texts) experienced the powerful impact of Kashtanov as a teacher who created a large scientific school of medievalists.

\section{Medieval, Diplomatic Acts in Russia. Formulary Analysis}

While he was still a student, S. M. Kashtanov's main focus was to study the grant acts of Russia. At the same time he took up the problems in studying documents on diplomacy, the development of types of forms and the methods of formulary analysis. For 60 years Kashtanov selflessly worked on textual and diplomatic charters [Каштанов, 1966; Каштанов, 1969a]. Studying the experience of Western European and Russian diplomatics from the $18^{\text {th }}-20^{\text {th }}$ centuries prompted him to rethink the subject, object and tasks of diplomatics as a science. He looked for the definition of "act" and "document", formulated his idea of diplomatics as a historical discipline, the subject of which are documents of a contractual nature and opposed the expansion of the term, "асt" [Каштанов, 1965a; Каштанов, 19696].

An important milestone in Kashtanov's studies became the publication in 1970 of his "Essays on Russian diplomatics." The book deals with the theory and methodology of formulary analysis, sets out how to study 
external and internal forms of documentary sources, the problems of their origin, content and their reliability. In this book Kashtanov first formulated the term "diplomatic form", distinguishing it from "conditional", "abstract", "concrete" and "individual" forms. After becoming a classic in the study of documents on diplomacy in Russia, his "Essays..." has been appreciated in our country and abroad [Каштанов, 1970a, с. 26-47].

In 1971 he published an article dedicated to the study of the titling of Russian princes' acts from the $10^{\text {th }}-14^{\text {th }}$ centuries. There Kashtanov attempted to divide this part of the form into redactions [Каштанов, 1976]. In 1972 S. M. Kashtanov turned for the first time to the reconstruction of the agreement-making procedure between Byzantium and Rus in 911 and 944 years, preserved as part of the Tale of Bygone Years. Applying the construction of F. Delger and I. Karayannopulos to their texts [Dolger, Karayannopulos], Kashtanov came to the conclusion that the form of these documents corresponds with two different schemes of agreement-making procedures. He showed that the main text of the treaty of 911 was made on behalf of the Russian side, and represents their oath-credentials. According to him, the agreement of 911 is comparable with the scheme of hrisovul of type II (composed by Byzantium without prior negotiation). In the arrangement of the same contract of 944 appear the two agreeing parties, i.e. Russians and Byzantines. Its form, according to Kashtanov, was made under the scheme of hrisovul of type I (i. e, written after preliminary negotiations). For the first time in historiography the difference in the structure of the text of treaties 911 and 944 years was explained by the peculiarities of the procedures for their conclusions [Каштанов, 1972]. Subsequently S. M. Kashtanov more than once turned to the study of Russian-Byzantine treaties of the $10^{\text {th }}$ century, offering his vision of their origin and their inclusion in the PVL.

In 1975, Kashtanov published an article on the study of the form of public law acts and of procedures for the award of contracts between the $10^{\text {th }}-14^{\text {th }}$ centuries. He showed that the stable structure of the acts occurred in Novgorod already between the $12^{\text {th }}-13^{\text {th }}$ centuries, whereas forms of princely acts in Ryazan, Tver and Moscow developed only towards the $14^{\text {th }}$ century. At the same time in Russia when "deal" acts prevailed (contractual, spiritual, charters), a genre of letters (poslanie) developed, which was considerably weaker than in the West at the same time. As a consequence, in practice the threat rarely was used such a component of form as notification (publication), and the most undeveloped part of it was the final protocol. Russian acts materials of this time generally lack an indication of date and place of issue. Sanctioning of public acts between the $12^{\text {th }}-13^{\text {th }}$ centuries were limited by a threat of Go's judgment, while the threatenng letters clause of the $14^{\text {th }}$ century already contains references to secular punishment [Каштанов, 1975].

Referring to the reconstruction of the relationship of donating princes and monasteries between the $14^{\text {th }}-16^{\text {th }}$ centuries, S. M. Kashtanov proposed the concept of the "theological preamble", implying the idea, which is for- 
mulated as an ideal goal of the award (1973). This expression is not identical to the invocation in the strictest sense, says Kashtanov, because it lacks the invocation of the name of God. Out of a desire to please the prince, document makers included a reference to the name of patron saint of the monastery, "St. Saviour sharing...., "the holy trinity sharing..." etc. This trend can be seen between the $14^{\text {th }}-15^{\text {th }}$ centuries, but it fizzles out by the end of the reign of Ivan III; in fact, it disappears at the time of the formation of the centralized state [Каштанов, 1973]. In 1979, he began to study the form of the grand spiritual letters from the $14^{\text {th }}-16^{\text {th }}$ centuries [Каштанов, 1979].

In 1988 Kashtanov published the monograph "Russian diplomatics". For the first time in historiography, its main subject focused on diplomatics in Russia and abroad. He emphasized the study of the origin and form of the acts of Russia between the $10^{\text {th }}-18^{\text {th }}$ centuries. They traced the distribution of various types of acts from the $10^{\text {th }}-20^{\text {th }}$ centuries, depending on the socio-political conditions of their appearance. A special section of the monograph is devoted to the problems of the methodology of diplomatics (Russian classification regulations, the study of their external and internal forms of internal and external content on the origin and function of acts) [Каштанов, 1988, с. 146-195].

In 1989, a study was published by S. M. Kashtanov on private acts and on the beginning of notaries in Russia. It contains not only an analysis of the earliest diplomatic Russian private acts but also of the unquestioned authenticity of the Spiritual (testament?) of Clement and "row" of Teshata and Yakim. When considering use of the word, "handwriting", in Acts, used almost exclusively to refer to one's spiritual credentials, Kashtanov suggested that the term originated in the period of transition from the practice of oral testaments to their written determination. According to him, "handwriting" is the most ancient kind of private acts in Russia. Turning to the origins of notaries in Russia, Kashtanov examines in detail the cases indicating the scribe and witnesses in private acts. He found that the professional scribes (clerks) of private acts do not appear before the middle of the $16^{\text {th }}$ century ("Square scribes"), although the earliest use of the word, "scribe", is recorded in that document of Teshata and Yakim in the last third of the $13^{\text {th }}$ century. The use of square clerks dies out in the $18^{\text {th }}$ century in connection with the registration of all private transactions in public institutions by "serfs clerks" [Kacshtanov, 1989].

In 1990, Kashtanov began studying contract ratification of Basil I and Metropolitan Cyprian on the confirmation of church charters of Vladimir I and Yaroslav the Wise; the eskhatokol contains the first references to Moscow. He provided compelling evidence for the dating of this act as from 1392 and showed that the precursors of the theory of "Moscow is the Third Rome" in the $14^{\text {th }}$ century arose in the church environment, even though they were caused by the political successes of the Moscow grand dukes. [Каштанов, 1990].

At the XVIII International Congress of Byzantine Studies (1991) Kashtanov made a presentation on charters of Moscow governments of the 
$16^{\text {th }}$ century to Athos monasteries, based on the study of the ancient "Greek" ambassadorial books [Kachtanov, 1991]. Then he concentrated on continuing to study Russian treaties with Byzantium princes in the $10^{\text {th }}$ century. He appealed to the interpretation of the expression "Ivanovy'm napisaniem na dvoyu Harati" in the contract of 911, which is contained in all the lists of the chronicles (1993). The word "Ivanovy'm", according to Kashtanov, is a distortion of the Greek " $\pi \alpha \rho \omega v$ " (real), which he suggested meant "real writing".

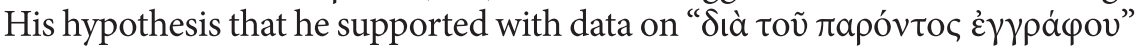
and its Latin equivalent "praesentibus" is well known in the texts of international treaties of Byzantium between the $11^{\text {th }}-12^{\text {th }}$ centuries. The appearance of the expression, "Ivanovy'm napisaniem", Kashtanov sees as the result of misstatements in a later translated and copied text of ratification. However, he did not rule out that the unclear expression could occur due to the general instability of the forms of international treaties of Byzantium, which finally formed at the end of the $10^{\text {th }}$ century [Каштанов, 1993].

In 1996 Kashtanov turned to the study of the expression "равно другаго свещания, бывшаго при..." ("ravno drugago sveshhaniya, by'vshago pri...") in the text of the treaties of the Chronicles of 911, 944 and 971, having concluded that these were unofficially translated copies of the letters of Russian-Byzantine treaties. According to him, the same initial parts of all three acts are indicative of simultaneous copying of Greek texts using a definite plan. Kashtanov suggested that the translations entered the Tale of Bygone Years no earlier than the last quarter of the $11^{\text {th }}$ century, and no later than the 1110-1112 period. At the same time Russian translations demonstrate that "Greek texts had evidence of copying from office copies of the era of Nicephorus III Votaniat or Alexius I Comnenus". The presence of the word "drugago" in the headlines of all three contracts, Kashtanov explained by a compilation of a kind of copy-book based on a register office. Each successive copy was separated from the previous title, stating that this is a copy of another contract. Similar expressions are found in a number of the copy-books of the Greek monasteries, in particular, Patmos [Каштанов, 19966].

In 1996 he published a fundamental monograph on the history of the Russian act since its inception in the $10^{\text {th }}$ century to the $16^{\text {th }}$ century, inclusive. The focus of this study (in contrast to the "Essays on Russian Diplomatics") is dedicated to the methodology of the research on acts, typology of forms, etc. Much attention is paid to the history and development of the formation of documentary sources. It is mainly focused on the study of public law (especially princes') acts. The book examines Russian-Byzantine treaties of the $10^{\text {th }}$ century, contracts of foreign policy from the $12^{\text {th }}-14^{\text {th }}$ centuries, princely acts of $12^{\text {th }}-14^{\text {th }}$ centuries and the internal control of charters of foreign policy of the $16^{\text {th }}$ century. Special investigation is given to the specificity of the initial protocol and disposition letters of Ryazan princes between the $14^{\text {th }}$ $16^{\text {th }}$ centuries, the issues of private acts in ancient Russia.

At the same time S. M. Kashtanov continued research into "Greek" ambassadorial books no. 1 and 2 in connection with the preparation of 
their publication. In 1997 he published an article on the evolution of the grand and royal title in the charters of the monastery of the $16^{\text {th }}$ century [Каштанов, 1997]. Kashtanov showed that the development of the grand and royal title in the charters of Mount Athos monasteries became more and more complicated. Use of the word "samoderzhecz" in headings first was observed in the charters of Fyodor Ioannovich in July 1589 to Kabardian princes, but the first known case of its inclusion in the official title refers to May of 1591. Kashtanov connects the earliest attempts to include the word "samoderzhecz" in a territorial title to the establishment of patriarchate in Russia (1589), and as a full territorial title, to the elimination of the inheritance of Prince Dmitry of Uglich (1591).

In the 2001 article, written in continuation of the theme of GreekRussian relations in the $16^{\text {th }}$ century, S. M. Kashtanov turned to the history of sending from Vatopetsky Monastery to Moscow, Savva, the Greek, "perevodchika knizhnovo na vremya", at the request of Vasily III to Athos monasteries' Simeon on March 15, 1515 [Каштанов, 2001]. According to Kashtanov, Savva came to Russia together with Maxim the Greek, was his associate and later became Archimandrite Spassky. Savva could take up this post during the time when Maxim the Greek was in favor, namely, in the period after September 1519 and before 1525 (i. e., before the condemnation of Maxim the Greek in the famous cathedral). Kashtanov expressed reasonable doubts that Maksim the Greek brought to Moscow the original hrisovula of Andronicus Paleologos. He suggested that, starting in Russia, Maxim the Greek "made himself or received a copy of one or more" hrisovulas [Каштанов, 2001, с. 213-214] . $^{6}$.

Since the sources give no reason to associate the name of Maxim the Greek with work done on past, everyday documentation, Kashtanov does not exclude the fact that the active clerical activity in Moscow was done by Savva. The end of the metropolitan monopoly in documenting relations with Orthodoxy abroad, Kashtanov connects with the beginning of the reform of the Izbrannaya Rada in 1549.

The subject of clerical practice of medieval Russia continued in the works of Kashtanov in connection with the investigation of the identity of the princely acts between the $13^{\text {th }}-16^{\text {th }}$ centuries (2001). In the princely acts, he has systematically examined the nomination of persons in charge of drawing up, approving and issuing documents. Analyzing the signature of the scribe in the row ("ryadnaya") of Teshata and Yakim ("А псал Довмонтовь писец" - "A psal Dovmontov' pisecz"), Kashtanov came to the conclusion that a scribe making a private act may be indicative of the performance of clerical duties along with also more notary functions. The scientistresearcher showed that the Moscow grand dukes had their own scribes in the first half of the $14^{\text {th }}$ century. He has consistently examined the cases that indicate a scribe in the grand spiritual acts (starting with the first spiritual act of Ivan Kalita), as well as in the testaments of the feudal princes

\footnotetext{
${ }^{6}$ Compare with the point of view of exporting not the copies, but the original charters: [Синицына].
} 
(starting with the spiritual act of Yuri Dmitrovsky, 1472). In spiritual acts, the use of an applied seal, rather than the more customary hanging seal, according to his conclusion, was a sign of lowering the political status of feudal princes in the second half of the $15^{\text {th }}$ century. At the end of $15^{\text {th }}$ and the first third of the $16^{\text {th }}$ centuries, feudal lords had not fastened their wills with their own seal, which indicated that the "spirituals of feudal princes shifted from political acts more into acts of individuals" [Каштанов, 2000].

\section{Theory and History of Feudal Property and Feudal Immunity}

A systematic study of Russian acts material from the $10^{\text {th }}-17^{\text {th }}$ centuries prompted S. M. Kashtanov to turn to the most important problems in the history of medieval Russia: feudal immunity, theory of feudal property, the history of financial (including tax) policy. The very first works by him in this direction (from the 50's and early 60's) demonstrate an innovative approach to determining the steps of immunity policy and political motives of awards of the governments of Vasily III and Ivan IV [Каштанов, 1957; Каштанов, 1958a; Каштанов, 1959; Каштанов, 1960; Каштанов, 1961]. In the period from 1963-1970, scientist the scholar focused on the study of the fate of the Church and monastic and secular immunity formation of caste system, as well as the abolition of tarkhans in 1575/76 [Каштанов, 19636; Каштанов, 1964; Каштанов, 19656].

In his article about Oprichnina policy of Ivan the Terrible (1963), Kashtanov concluded (perhaps somewhat exaggeratingly) that socially the Oprichnina policy strengthened the enslavement of peasants. However, the main merit of the author is in the proof of anti- local feudal orientation of Oprichnina. He brilliantly showed that in the 60's - early 70's of the $16^{\text {th }}$ century the union of Royal power with the cities was destroyed (in favor of the monasteries). During this period, some privileged monasteries gained property as a result of the sovereign's generous awards [Каштанов, 1963a].

In 1967, S. M. Kashtanov published a brilliant monograph on the socio-political history of Russia in the late $15^{\text {th }}$ and the first half of the $16^{\text {th }}$ centuries [Каштанов, 1967]. This work continued his work, which was started in his thesis and dissertation papers, and he included in it a large section on the policy of immunity of Ivan III (until 1505); then he turned to the study of the domestic policy of Vasily III and the regency of Elena Glinskaya during the boyar rule. Kashtanov considered the history of immunity in connection with other parties' internal policies of the governments of Russia in the late $15^{\text {th }}$ and first half of the $16^{\text {th }}$ century. The book established the causes of charters and letters, of ukazy in 1492-1548 years, and characterizes the changes they made to feudal immunity in Russia. It was shown that immunity ratification in the years between 14921505 demonstrated the breakdown of the old feudal rules of immunity. In the period between 1505-1537, its fate was closely linked with the history of the feudal lands. Major political events of the time (including the issuance 
of immunity letters) were associated with an active policy of the central government towards the separation of local feudal lords. The scientist scholar found that the period between 1538-1548 showed the significant growth of the monastic tarkhan privileges, which is seen to accompany the growing power of the Government of Izbrannaya Rada.

In 1970 S. M. Kashtanov published a pioneering article on the theory of ownership and feudal immunity. In this article, he offers interpretations of the concepts "immunity", "property" and "non-economic coercion" [Каштанов, 19706] $]^{7}$. A year later he published an article in Cambridge about the immunity policy between the $15^{\text {th }}-16^{\text {th }}$ centuries. In it he summarized the main findings of the socio-political history of Russia and described trends in the development of feudal immunity in the period of forming and strengthening of the centralized state [Kashtanov, 1971]. He came back to the theory of feudal property in 2001, referring to the clarification of terms: "property", "ownership" and "use" [Собственность в России].

In 1974 Kashtanov published a voluminous article devoted to the study of a link between land deposits in the Trinity-Sergius Monastery and the composition of the cathedral elders. He reviewed the history of the change of Troiczk abbots in the middle of the 16th century (especially of Ioasaf, Jonah, Serapion and Artemiy) and studied the many letters that streamed into this abode in the period of the cancellation of tarkhans. For the first time in historiography, Kashtanov succeeded in defining a whole set of Trinity cathedral elders in late 40's and early 50 's in the $16^{\text {th }}$ century [Каштанов, 1974].

Акты Русского государства 1505-1526 гг. М., 1975. 435 с.

Акты феодального землевладения и хозяйства. Акты Московского Симонова монастыря (1506-1613 гг.) / под ред. Л. И. Ивиной. Л., 1983.

Грамоты из архива Московского Архангельского собора // Археографический ежегодник за 1997 год / под ред. С. М. Каштанова, О. И. Хоруженко. М., 1997. C. 390-438.

Каштанов С. М. Актовая археография. М., 1998. 318 с.

Каштанов С. М. Богословская преамбула жалованных грамот // Вспомогательные исторические дисциплины. Л., 1973. Вып. 5. С. 81-107.

Каштанов С. М. Грамоты Московского Симонова монастыря как источник для изучения вопроса об отмене тарханов в 1575/76 г. // Исследования по отечественному источниковедению. М.; Л., 1964. С. 499-503.

Каштанов С. М. Дипломатика как специальная историческая дисциплина // Вопросы истории. 1965а. № 1. С. 39-44.

Каштанов С. М. Дипломатический состав древнерусского акта // Вспомогательные исторические дисциплины. Л., 1969а. Вып. 2. С. 143-159.

Каштанов С. М. Договор России с Ливонией 1535 г. // Проблемы источниковедения. М., 2006а. Вып. 1 (12). С. 167-297.

Каштанов С. М. Из истории последних уделов // Труды МГИАИ. М., 1957. Т. 10. C. 257-302.

Каштанов С. М. Из истории русского средневекового источника: Акты X-XVI вв. М., 1996а. 266 c.

${ }^{7}$ His theory of feudal property formed the basis of the studies of L. E. Kubbel, who confirmed the correctness of Kashtanov's constructions on African materials: [Куббель, c. 258]. 
Каштанов С. М. Из опыта актовой археографии // Археографический ежегодник за 1982 год. М., 1983. С. 52-79.

Каштанов С. М. Иммунитетные грамоты 1534 - начала 1538 г. как источник по истории внутренней политики в период регентства Елены Глинской // Проблемы источниковедения. М., 1959. Вып. 8. С. 372-420.

Каштанов С. М. Интитуляция русских княжеских актов X-XIV вв. (Опыт первичной классификации) // Вспомогательные исторические дисциплины. Л., 1976. Вып. 8. С. 69-83.

Каштанов С. М. Исследование о молдавской грамоте XV века. М., 2012.

Каштанов С. М. Исследования по истории княжеских канцелярий средневековой Руси. М., 2014. С. 483-638.

Каштанов С. М. К вопросу о происхождении текста русско-византийских договоров X в. в составе Повести временных лет // Восточная Европа в древности и средневековье. М., 1996б. С. 39-42.

Каштанов С. М. К вопросу об отмене тарханов в 1575/76 г. // Исторические записки. 1965б. Т. 77. С. 209-235.

Каштанов С. М. К изучению опричнины Ивана Грозного // История СССР. $1963 \mathrm{a}$. № 2. C. $96-117$.

Каштанов С. М. К изучению формуляра великокняжеских духовных грамот конца XIV - начала XVI в. // Вспомогательные исторические дисциплины. Л., 1979. Вып. 11. С. 238-251.

Каштанов С. М. К истории русско-греческих культурных связей в XVI в. // MOCXО-

BIA. Проблемы византийской и новогреческой филологии. М., 2001. С. 209-218.

Каштанов С. М. К истории холопства в XVI в. // Времена и судьбы: сб. ст. в честь 75-летия В. М. Панеяха. СПб., 2006б. С. 357-380.

Каштанов С. М. К предыстории идеи «Москва - третий Рим» // Общественное сознание, книжность, литература периода феодализма. Новосибирск, 1990. С. 262273.

Каштанов С. М. Монастырские документы о политической борьбе середины XVI в. // Археографический ежегодник за 1973 год. М., 1974. С. 29-42.

Камтанов С. М. О внутренней политике Ивана Грозного в период «великого княжения» Симеона Бекбулатовича // Труды МГИАИ. М., 1961. Т. 16. С. 427-462.

Каштанов С. М. О выражении «Ивановым написанием» в летописном тексте русско-византийского договора 911 г. // Восточная Европа в древности и средневековье. М., 1993. С. 33-34.

Каштанов С. М. О написании и удостоверении княжеских актов // Российское самодержавие и бюрократия. М.; Новосибирск, 2000. С. 29-49.

Каштанов С. М. О процедуре заключения договоров между Византией и Русью в

Х в. // Феодальная Россия во всемирно-историческом процессе. М., 1972. С. 209-215.

Каштанов С. М. Общие жалованные грамоты Троице-Сергиеву монастырю 1550 ,

1577 и 1578 гг. на все вотчины (соотношение текстов) // Записки Отдела рукописей Государственной библиотеки им. В. И. Ленина. М., 1966. Вып. 28. С. 96-142.

Каштанов С. М. Ограничение феодального иммунитета правительством Русского централизованного государства в 1-й трети XVI в. // Труды МГИАИ. М., 1958а. Т. 11. C. $269-296$.

Каштанов С. М. Очерки русской дипломатики. М., 1970а.

Каштанов С. М. Предмет, задачи и методы дипломатики // Источниковедение: Теоретические и методические проблемы. М., 1969б. С. 134-170.

Каштанов С. М. Русская дипломатика. М., 1988а.

Каштанов С. М. Русские княжеские акты X-XIV вв. (до 1380 г.) // Археографический ежегодник за 1974 год. М., 1975. С. 94-116.

Каштанов С. М. Современные принципы издания латинских грамот [Ч. 1] // Археографический ежегодник за 1983 год. М., 1985. С. 37-48.

Каштанов С. М. Современные принципы издания латинских грамот [Ч. 2] // Археографический ежегодник за 1984 год. М., 1986а. С. 75-87.

Каштанов С. М. Современные принципы издания латинских грамот [Ч. 3] // Археографический ежегодник за 1985 год. М., 1986б. С. 52-67.

Каштанов С. М. Современные принципы издания латинских грамот [Ч. 4] // Археографический ежегодник за 1986 год. М., 1987. С. 46-58.

Каштанов С. М. Современные принципы издания латинских грамот [Ч. 5] // Археографический ежегодник за 1987 год. М., 1988б. С. 35-44. 
Каштанов С. М. Состав иммунитетных грамот первой половины XVI в. // Археографические записки за 1962 год. М., 1963б. С. 98-110.

Каштанов С. М. Социально-политическая история России конца XV - первой половины XVI в. М., 1967. 392 с.

Каштанов С. М. Феодальный иммунитет в годы боярского правления (1538-1548)

// Исторические записки. 1960. Т. 66. С. 239-268.

Каштанов С. М. Феодальный иммунитет в свете марксистско-ленинского учения о земельной ренте // Актуальные проблемы истории России эпохи феодализма. М., 1970б. С. 172-173, 193, 198.

Каштанов С. М. Хронологический перечень иммунитетных грамот XVI в. [Часть 1] // Археографический ежегодник за 1957 год. М., 1958б. С. 302-376. Каштанов C. M. Хронологический перечень иммунитетных грамот XVI в. [Часть 2] // Археографический ежегодник за 1960 год. М., 1962. С. 129-200. Каштанов C. М. Ценное свидетельство о земской реформе середины XVI в. // Советское архивоведение. 1968. № 5. С. 49-54. Каштанов С. М. Чертеж земельного участка XVI в. // Труды МГИАИ. Т. 17. М., 1963в. С. $429-436$.

Каштанов С. М. Эволюция великокняжеского и царского титула в грамотах афонским монастырям XVI в. // Россия и христианский Восток. М., 1997. Вып. 1. C. $105-134$.

Каштанов С. М., Назаров В. Д., Флоря Б. Н. Хронологический перечень иммунитетных грамот XVI в. [Часть 3] // Археографический ежегодник за 1966 год. M., 1968. C. 197-253.

Каштанов С. М., Робинсон А. Н. Две жалованные грамоты псковским монастырям // Записки Отдела рукописей Государственной библиотеки СССР им. В. И. Ленина. М., 1961. Вып. 24. С. 221-258.

Каштанов С. М., Хорошкевич А. Л. Методические рекомендации по изданию и описанию Литовской метрики. Вильнюс, 1985. 133 с.

Кистерев С. Н. Новое издание документов о России и греческом мире в XVI веке

// Очерки феодальной России. М., 2005. Вып. 9. С. 311-334.

Куббель Л.Е. Сонгайская держава. М. 1974. С. 258.

Никитин Н. И. Письмо в редакцию: Об «усложненных» и «упрощенных» правилах издания актовых источников // Отечественные архивы. 1993. № 4. С. 120-121.

Новонайденная жалованная грамота Ивана III и Василия III 1504 г. Спасскому Валаамскому монастырю / подг. С. М. Каштановым, Е. Е. Матвеевой; послесл. о. Онуфрия, Спасо-Валаамский монастырь // Археографисеский ежегодник за 2000 год. М., 2001. С. 419-447.

Отдаточные книги Троице-Сергиева монастыря 1649-1650 гг. // Исторический архив. Т. 8. М. ; Л, 1953. С. 198-220.

Памятники русского права. М., 1955. Вып. 3. С. 83-150. М., 1956. Вып. 4. С. 99170, 287-289. М., 1959. Вып. 5. С. 47-134.

Правила издания «Актов Русского государства XVI - начала XVII в.» / И. А. Булыгин. М., 1984.

РГАДА. Ф. 64: Сношения России с Лифляндией и Эстляндией. Оп. 2. № 7. Л. 1-2.

Россия и греческий мир в XVI в. Т. 1 / под ред. С. М. Каштанова, Л. В. Столяровой. M., 2004. 527 c.

Синицына Н. В. Послание Максима Грека Василию III об устройстве афонских монастырей (1518-1519 гг.) // Византийский временник. Т. 26. М., 1965. С. 130.

Собственность в России: Средневековье и раннее новое время. М., 2001. С. 7-40. Сокращенный летописный свод 1493 г. // Полное собрание русских летописей. М., 1962. Вып. 27. С. 7-10, 163-298.

Сокращенный летописный свод 1495 г. // Полное собрание русских летописей. М., 1962. Вып. 27. С. 10-14, 299-367.

Столярова Л. В. Проблемы истории феодальной России в творчестве Сергея Михайловича Каштанова // Ad fontem = У источника: сб. статей в честь Сергея Михайловича Каштанова. М., 2005. С. 7-77.

Успенский сборник XII-XIII вв. / подг. О. А. Князевской, В. Г. Демьяновым, М. В. Ляпон; под ред. С. И. Коткова. М., 1971. 754 с. С. 26-28.

Dolger F., Karayannopulos J. Byzantinische Urkundenlehre. München, 1968. 1. Abschnitt. S. 97-104. 
Kashtanov S. M. The Centralized State and Feudal Immunities in Russia // The Slavonic and East European Review. London, 1971. Vol. 49. № 115. P. 235-254.

Kacshtanov S. M. Les actes privés et le début du notariat en Russie // Notariado público y documento privado: de los origenes al siglo XIV. Actas del VII Congreso International de Diplomatica Valencia, 1989. Vol. 2. P. 927-928.

Kachtanov $S . M$. Les chartes des grands-princes et tzars de la Russie aux monastères du Mont Athos (XVIe siècle) // XVIII Междунар. конгресс византинистов. М., 1991. Ч. 1. C. $498-499$.

Akty' Russkogo gosudarstva 1505-1526 gg. [Acts of Russian state 1505-1526 yrs.]. (1975). Moscow.

Buly'gin, I. A. (Comp.). (1984). Pravila izdaniya «Aktov Russkogo gosudarstva XVInachala XVII v.» [The rules of publication of the "Acts of Russian state of the $16^{\text {th }}$ - early $17^{\text {th }}$ c." $]$. Moscow.

Dolger, F. \& Karayannopulos, J. (1968). Byzantinische Urkundenlehre (pp. 97-104). München.

Ivina, L. I. (Ed.). (1983). Akty' feodal'nogo zemlevladeniya i hozyajstva. Akty' moskovskogo Simonova monasty'rya (1506-1613 gg.). [Acts of feudal tenure and economy. Acts of Moscow Simon monastery (1506-1613 yrs.)]. Leningrad.

Kashtanov, S. M. (1957). Iz istorii poslednih udelov [From the history of last domains]. In Trudy' MGIAI. (Vol. 10, pp. 257-302). Moscow.

Kashtanov, S. M. (1958). Hronologicheskij perechen' immunitetny'h gramot XVI v. [Chronological list of immunity charters of the $16^{\text {th }} \mathrm{c}$.]. (Part 1). In Arheograficheskij ezhegodnik za 1957 god (pp. 302-376). Moscow.

Kashtanov, S. M. (1958). Ogranichenie feodal'nogo immuniteta pravitel'stvom Russkogo centralizovannogo gosudarstva v pervoj treti XVI v. [Restriction of feudal immunities by Russian centralized state in the first third of the $16^{\text {th }} \mathrm{c}$.]. In Trudy' MGIAI. (Vol. 11, pp. 269-296). Moscow.

Kashtanov, S. M. (1959). Immunitetny'e gramoty 1534 - nachala 1538 g. kak istochnik po istorii vnutrennej politiki v period regentstva Eleny' Glinskoj [Immunity charters in 1534 - early 1538 yr. as a source of the history of internal policy during Elena Glinskaya regency]. In Problemy' istochnikovedeniya. (Vol. 8, pp. 372-420). Moscow.

Kashtanov, S. M. (1960). Feodal'nyj immunitet v gody' boyarskogo pravleniya (15381548) [Feudal immunities during boyar government (1538-1548)]. In Istoricheskie zapiski. (Vol. 66, pp. 239-268).

Kashtanov, S. M. (1961). O vnutrennej politike Ivana Groznogo v period «velikogo knyazheniya» Simeona Bekbulatovicha [On internal policy of Ivan the Terrible during "great reign" of Simeon Bekbulatovich]. In Trudy' MGIAI. (Vol. 16, pp. 427-462). Moscow.

Kashtanov, S. M. \& Robinson, A. N. (1961). Dve zhalovanny'e gramoty' pskovskim monasty'ryam [Two grant-charters to Pskov monasteries]. In Zapiski Otdela Rukopisej Gosudarstvennoi biblioteki SSSR im. V. I. Lenina. (Vol. 24, pp. 221-258). Moscow.

Kashtanov, S. M. (1962). Hronologicheskij perechen' immunitetny'h gramot XVI v. [Chronological list of immunity charters of the $16^{\text {th }} \mathrm{c}$.]. (Part 2). In Arheograficheskij ezhegodnik za 1960 god (pp. 129-200). Moscow.

Kashtanov, S. M. (1963). Chertezh zemel'nogo uchastka XVI v. [Draft of a land lot in the $16^{\text {th }}$ c.]. In Trudy' MGIAI. (Vol. 17, pp. 429-436).

Kashtanov, S. M. (1963). K izucheniyu oprichniny' Ivana Groznogo [On studying orichnina of Ivan the Terrible]. Istoriya SSSR, 2, 96-117.

Kashtanov, S. M. (1963). Sostav immunitetny'h gramot pervoj poloviny' XVI v. [Contents of immunity charters of the first half of the $16^{\text {th }} \mathrm{c}$.]. In Arheograficheskij ezhegodnik za $1962 \operatorname{god}$ (pp. 98-100). Moscow.

Kashtanov, S. M. (1964). Gramoty' Moskovskogo Simonova monasty'rya kak istochnik dlya izucheniya voprosa ob otmene tarhanov v 1575/76 g. [Charters of Moscow Simon monastery as a source for studying the question on tarkhan withdrawal in 1575/76 yr.]. In Issledovaniya po otechestvennomu istochnikovedeniyu (pp. 499-503). Moscow; Leningrad.

Kashtanov, S. M. (1965). Diplomatika kak special'naya istoricheskaya disciplina [Diplomatics as a special historical discipline]. Voprosy' istorii, 1, 39-44.

Kashtanov, S. M. (1965). K voprosu ob otmene tarhanov v 1575/76 g. [Revisiting the tarkhan withdrawal in 1575/76 yr.]. In Istoricheskie zapiski. (Vol. 77, pp. 209-235). 
Kashtanov, S. M. (1966). Obshhie zhalovanny'e gramoty' Troice-Sergievu monasty'ryu 1550,1577 i 1578 gg. na vse votchiny' (sootnoshenie tekstov) [General grant-charters to the Trinity Lavra of St. Sergius of 1550, 1577 and 1578 yrs. for all the lands (correspondence of texts)]. In Zapiski Otdela rukopisej Gosudarstvennoj biblioteki SSSR im. V. I. Lenina. (Vol. 28, pp. 96-142). Moscow.

Kashtanov, S. M. (1967). Social'no-politicheskaya istoriya Rossii koncza XV-pervoj poloviny' XVI v. [Politico-social history of Russia of the late $15^{\text {th }}-$ first half $16^{\text {th }} \mathrm{c}$.]. Moscow.

Kashtanov, S. M. (1968). Cennoe svidetel'stvo o zemskoj reforme serediny' XVI v. [Valuable evidence on land reform in the middle of the $16^{\text {th }} \mathrm{c}$.]. Sovetskoe arhivovedenie, $5,49-54$.

Kashtanov, S. M., Nazarov, V. D. \& Florya, B. N. (1968). Hronologicheskij perechen' immunitetnyh gramot XVI v. [Chronological list of immunity charters in the XVI c.]. (Part 3). In Arheograficheskij ezhegodnik za 1966 god (pp. 197-253). Moscow.

Kashtanov, S. M. (1969). Diplomaticheskij sostav drevnerusskogo akta [Diplomatic contents of an Old Russian act]. In Vspomogatel'ny'e istoricheskie discipliny'. (Vol. 2, pp. 143-159). Leningrad.

Kashtanov, S. M. (1969). Predmet, zadachi i metody' diplomatiki [Object, tasks and methods of diplomatics]. In Istochnikovedenie: Teoreticheskie i metodicheskie problemy' (pp. 134-170). Moscow.

Kashtanov, S. M. (1970). Feodal'ny'j immunitet v svete marksistsko-leninskogo ucheniya o zemel'noj rente [Feudal immunity in the light of Marxist-Leninist teaching of land rent]. In Aktual'ny'e problemy' istorii Rossii e'pohi feodalizma (pp. 172-173, 193, 198). Moscow.

Kashtanov, S. M. (1970). Ocherki russkoj diplomatiki [Essays of Russian diplomatics] (pp. 341-448). Moscow.

Kashtanov, S. M. (1971). The Centralized State and Feudal Immunities in Russia. The Slavonic and East European Review, 49, 115, 235-254. London.

Kashtanov, S. M. (1972). O procedure zaklyucheniya dogovorov mezhdu Vizantiej i Rus'yu v X v. [On the procedure of concluding treaties between Byzantium and Russia in the $10^{\text {th }}$ c.]. In Feodal'naya Rossiya vo vsemirno-istoricheskom processe (pp. 209-215). Moscow.

Kashtanov, S. M. (1973). Bogoslovskaya preambula zhalovanny'h gramot [Theological preamble of grant-charters]. In Vspomogatel'ny'e istoricheskie discipliny'. (Vol. 5, pp. 81-107). Leningrad.

Kashtanov, S. M. (1974). Monasty'rskie dokumenty' o politicheskoj bor'be serediny' XVI v. [Monastery documents on political struggle in the middle of the $16^{\text {th }} \mathrm{c}$.]. In Arheograficheskij ezhegodnik za 1973 god (pp. 29-42). Moscow.

Kashtanov, S. M. (1975). Russkie knyazheskie akty' X-XIV vv. (do 1380 g.) [Russian princely acts of $10^{\text {th }}-14^{\text {th }} \mathrm{cc}$. (till $1380 \mathrm{yr}$.)]. In Arheograficheskij ezhegodnik za $1974 \mathrm{god}$ (pp. 94-116). Moscow.

Kashtanov, S. M. (1976). Intitulyaciya russkih knyazheskih aktov X-XIV vv. (Opy't pervichnoj klassifikacii) [Entitlement of Russian princely acts of the $10^{\text {th }}-14^{\text {th }} \mathrm{cc}$. (Attempt of primary classification)]. In Vspomogatel'ny'e istoricheskie discipliny'. (Vol. 8, pp. 6983). Leningrad.

Kashtanov, S. M. (1979). K izucheniyu formulyara velikoknyazheskih duhovny'h gramot koncza XIV - nachala XVI v. [On studying the forms of grand prince spiritual charters of the late $14^{\text {th }}-$ early $16^{\text {th }} \mathrm{c}$.]. In Vspomogatel'ny'e istoricheskie discipliny'. (Vol. 11, pp. 238-251). Leningrad.

Kashtanov, S. M. (1983). Iz opy'ta aktovoj arheografii [From act archeography experience]. In Arheograficheskij ezhegodnik za 1982 god (pp. 52-79). Moscow.

Kashtanov, S. M. (1985). Sovremenny'e principy' izdaniya latinskih gramot [Modern principles of publication of latin charters]. (Part 1). In Arheograficheskij ezhegodnik za 1983 god (pp. 37-48). Moscow.

Kashtanov, S. M. \& Horoshkevich, A. L. (1985). Metodicheskie rekomendacii po izdaniyu i opisaniyu Litovskoj metriki [Guidelines on publication and description of Lithuanian metrics]. Vilnyus.

Kashtanov, S. M. (1986). Sovremenny'e principy' izdaniya latinskih gramot [Modern principles of publication of latin charters]. (Part 2). In Arheograficheskij ezhegodnik za 1984 god (pp. 75-87). Moscow. 
Kashtanov, S. M. (1986). Sovremenny'e principy' izdaniya latinskih gramot [Modern principles of publication of latin charters]. (Part 3). In Arheograficheskij ezhegodnik za 1985 god (pp. 52-67). Moscow.

Kashtanov, S. M. (1987). Sovremenny'e principy' izdaniya latinskih gramot [Modern principles of publication of latin charters]. (Part 4). In Arheograficheskij ezhegodnik za 1986 god (pp. 46-58). Modern.

Kashtanov, S. M. (1988). Russkaya diplomatika [Russian diplomatics]. Moscow.

Kashtanov, S. M. (1988). Sovremenny'e principy' izdaniya latinskih gramot [Modern principles of publication of latin charters]. (Part 5). In Arheograficheskij ezhegodnik za $1987 \operatorname{god}$ (pp. 35-44). Moscow.

Kashtanov, S. M. (1989). Les actes privés et le début du notariat en Russie. In Notariado público y documento privado: de los origenes al siglo XIV. Actas del VII Congreso International de Diplomatica. (Vol. 2, pp. 927-928). Valencia.

Kashtanov, S. M. (1990). K predy'storii idei "Moskva - tretij Rim" [Prehistory of the idea "Moscow - the third Rome"]. In Obshhestvennoe soznanie, knizhnost', literatura perioda feodalizma (pp. 262-273). Novosibirsk.

Kashtanov, S. M. (1991). Les chartes des grands-princes et tzars de la Russie aux monastères du Mont Athos (XVI siècle). In XVIII Mezhdunarodny'j kongress vizantinistov. (Part 1, pp. 498-499). Moscow.

Kashtanov, S. M. (1993). O vy'razhenii «Ivanovy'm napisaniem» v letopisnom tekste russko-vizantijskogo dogovora $911 \mathrm{~g}$. [About expression "Ivanovym napisaniem" in the annalistic text of the Russian-Byzantine Treaty of 911 yr.]. In Vostochnaya Evropa v drevnosti i srednevekov'e (pp. 33-34). Moscow.

Kashtanov, S. M. (1996). Iz istorii russkogo srednevekovogo istochnika: Akty' X-XVI $v v$. [From the history of Russian medieval source: Acts of the $10^{\text {th }}-16^{\text {th }} \mathrm{cc}$.]. Moscow.

Kashtanov, S. M. (1996). K voprosu o proishozhdenii teksta russko-vizantiiskih dogovorov X v. v sostave Povesti vremenny'h let [Revisiting the origin of the text of RussianByzantine treaties of the $10^{\text {th }} \mathrm{c}$. as a part of the Tale of Bygone Years]. In Vostochnaya Evropa $v$ drevnosti i srednevekov'e (pp. 39-42). Moscow.

Kashtanov, S. M. (1997). E'volyuciya velikoknyazheskogo i czarskogo titula v gramotah afonskim monasty'ryam XVI v. [Evolution of the grand prince and tsar's title in the charters to Athos monasteries in the $16^{\text {th }}$ c.]. In Rossiya i hristianskij Vostok. (Iss. 1, pp. 105-134). Moscow.

Kashtanov, S. M. (1998). Aktovaya arheografiya [Act archaeography]. Moscow.

Kashtanov, S. M. (2000). O napisanii i udostoverenii knyazheskih aktov [On writing and verification of princely acts]. In Rossijskoe samoderzhavie i byurokratiya (pp. 29-49). Moscow; Novosibirsk.

Kashtanov, S. M. (2001). K istorii russko-grecheskih kul'turny'h svyazej v XVI v. [To the history of Russian-Greek cultural contacts]. In Mosxovia: Problemy' vizantiiskoj i novogrecheskoj filologii (pp. 209-218). Moscow.

Kashtanov, S. M. (2006). Dogovor Rossii s Livoniej 1535 g. [Russian-Livonian treaty of 1535 yr.]. In Problemy' istochnikovedeniya. (Iss. 1 (12), pp. 167-297). Moscow.

Kashtanov, S. M. (2006). K istorii holopstva v XVI v. [On the history of velleinage of the $16^{\text {th }}$ c.]. In Vremena $i$ sud'by': Sbornik statej $v$ chest' 75-letiya V. M. Paneyaha (pp. 357-380). St. Petersburg.

Kashtanov, S. M. (2012). Issledovanie o moldavskoj gramote XV veka [Research on Moldavian charter of the $15^{\text {th }}$ century]. Moscow.

Kashtanov, S. M. (2014). Issledovaniya po istorii knyazheskih kancelyarij srednevekovoj Rusi [Researches on the history of the princely office in the medieval Russia] (pp. 483-638). Moscow.

Kashtanov, S. M. \& Horuzhenko, O. I. (Eds.). (1997). Gramoty' iz arhiva Moskovskogo Arhangel'skogo sobora [Charters from the archive of the Archangel Michael Cathedral in Moscow]. In Arheograficheskij ezhegodnik za 1997 god (pp. 390-438). Moscow.

Kashtanov, S. M. \& Matveeva, E. E. (Eds.). (2001). Novonajdennaya zhalovannaya gramota Ivana III i Vasiliya III 1504 g. Spasskomu Valaamskomu monasty'ryu [Newly 
found grant-charter of Ivan III and Vasily III of 1504 yr. to Spassky Valaam Monastery]. Father Onuphrius, Spaso-Valaam Monastery (Afterword). In Arheograficheskij ezhegodnik za 2000 god (pp. 419-447). Moscow.

Kashtanov, S. M. \& Stolyarova, L. V. (Eds.). (2004). Rossiya i grecheskij mir v XVI veke [Russia and Greek world in the $16^{\text {th }}$ century]. (Vol. 1). Moscow.

Kisterev, S. N. (2005). Novoe izdanie dokumentov o Rossii i grecheskom mire v XVI veke [New edition of documents in Russia and Greek world in the $16^{\text {th }}$ century]. In Ocherki feodal'noj Rossii. (Vol. 9, pp. 311-334). Moscow.

Knyazevskaya, O. A., Dem'yanov, V. G. \& Lyapon, M. V. (Eds.). (1971). Uspenskij sbornik XII-XIII vv. [Uspensky collection of the $10^{\text {th }}-13^{\text {th }} \mathrm{cc}$.] (pp. 26-28). Moscow.

Kubbel', L. E. (1974). Songajskaya derzhava [Songhai power]. Moscow.

Nikitin, N. I. (1993). Pis'mo v redakciyu: Ob «uslozhnenny'h» i «uproshhennyh'» pravilah izdaniya aktovy'h istochnikov [A letter to the editorial: On "complicated" and "simplified" rules of publishing act sources]. Otechestvenny'e arhivy', 4, 120-121.

Otdatochny'e knigi Troice-Sergieva monasty'rya 1649-1650 gg. [Returning books of Trinity Lavra of St. Sergius in 1649-1650 yrs.]. (1953). In Istoricheskij arhiv. (Vol. 8, pp. 198-220).

Pamyatniki russkogo prava [Monuments of Russian law]. (1955). (Vol. 3, pp. 83-150). Moscow; (1956). (Vol. 4, pp. 99-170, 287-289). Moscow; (1959). (Vol. 5, pp. 47-134). Moscow.

RGADA. Fond 64: Snosheniya Rossii s Liflyandiej i E'stlyandiej. Op. 2. № 7. L. 1-2 [Russian state archive of ancient acts. Stock 64: Relations between Russia and Livonia and Esthonia. List 2. № 7. Leaf 1-2.].

Sinicy'na, N. V. (1965). Poslanie Maksima Greka Vasiliyu III ob ustrojstve afonskih monasty'rei (1518-1519 gg.) [Letter of Maximus the Greek to Vasily III about the organization of Athos monasteries]. In Vizantijskij vremennik. (Vol. 26, p. 130).

Sobstvennost'v Rossii: Srednevekov'e i rannee novoe vremya [Property in Russia: middle ages and early modern period]. (2001). (pp. 7-40). Moscow.

Sokrashhenny'j letopisny'j svod 1493 g. [Brief chronicle of 1493 yr.]. (1962). In Polnoe Sobranie Russkih Letopisej. (Vol. 27, pp. 7-10, 163-298). Moscow.

Sokrashhenny'j letopisny'j svod 1495 g. [Brief chronicle of 1495 yr.]. (1962). In Polnoe Sobranie Russkih Letopisej. (Vol. 27, pp. 10-14, 299-367). Moscow.

Stolyarova, L. V. (2005). Problemy' istorii feodal'noj Rossii v tvorchestve Sergeya Mihajlovicha Kashtanova [The problems of feudal Russia in works of Sergey Mikhailovich Kashtanov]. In Ad Fontem=U istochnika: Sbonik statej v chest' Sergeya Mihajlovicha Kashtanova (pp. 7-77). Moscow.

The article was submitted on 21.08.2014

\section{Столярова Любовь Викторовна} д. и. н.

Россия

Институт всеобщей истории РАН lvsto@mail.ru

\section{Королева Светлана Юрьевна}

научный сотрудник

Россия

Институт всеобщей истории РАН korolevoy@mail.ru

\author{
Stolyarova Lyubov', Dr \\ Russia \\ Institute of World History, Russian \\ Academy of Sciences \\ lvsto@mail.ru
}

\author{
Koroleva Svetlana \\ Researcher \\ Russia \\ Institute of World History, Russian \\ Academy of Sciences \\ korolevoy@mail.ru
}

